\title{
A Novel, Improved, Application for the Normalization of RNA-seq Expression Data in Complex Polyploids
}

Dyfed Lloyd Evans ${ }^{1,2}$

${ }^{1}$ South African Sugarcane Research Institute

${ }^{2}$ Cambridge Sequence Services (CSS)

July 27, 2021

\section{Hosted file}

RNA-seq_Code_Paper2.pdf available at https://authorea.com/users/427772/articles/531888-anovel-improved-application-for-the-normalization-of-rna-seq-expression-data-in-complexpolyploids 